\section{Results of the ACTION-IO survey in Chilean patients with obesity and health care providers}

\author{
ADA CUEVAS ${ }^{1,2, *}$, RODRIGO ALONSO $^{1,2}$, ÁLVARO CONTRERAS $^{3}$, \\ DENISSE MONTT ${ }^{4}$, ADRIANA RENDON $^{5}$
}

\section{ABSTRACT}

Background: Most of the Chilean population has overweight or obesity. The ACTION-IO survey identified the perceptions, attitudes, and barriers to effective obesity care in people with obesity $(\mathrm{PwO})$ and healthcare professionals (HCPs). Aim: To report the results of the survey in Chile. Material and Methods: An online survey was conducted in 11 countries. In Chile, eligible PwO were adults with a body mass index $\geq 30 \mathrm{~kg} / \mathrm{m}^{2}$. Eligible HCPs were physicians involved in direct patient care. Results: The survey was completed by 1,000 PwO and 200 HCPs in Chile. Seventy four percent of PwO and 95\% of HCPs agreed that obesity was a chronic disease. Most $P w O(79 \%)$ assumed responsibility for their own weight loss, while 47\% of HCPs considered weight loss to be the sole responsibility of their patients. Both $82 \%$ of $P w O$ and $97 \%$ of HCPs believed that lack of exercise was a key barrier to weight loss. Sixty six percent of PwO and 58\% HCPs noted that the cost of weight management medications, programs, and services was another barrier. Compared with $\mathrm{HCPs}$, more PwO felt that genetic factors prevented weight loss (26 and $44 \%$ respectively). Few HCPs (19\%) thought that their patients were motivated to lose weight, while $55 \%$ of $P w O$ reported being motivated. Most (70\%) PwO had discussed their weight problem with their HCP in the past 5 years, and of those that had not, $89 \%$ want their HCP to start a discussion about weight. Conclusions: Chilean data reveal misconceptions among PwO and HCPs about obesity and highlights the need to improve education about its biologic background and clinical management.

(Rev Med Chile 2021; 149: 217-228)

Key words: Health Personnel; Obesity; Perception.

\section{Resultados de la encuesta ACTION-IO en pacientes con obesidad y profesionales de la salud chilenos}

Antecedentes: La población chilena tiene una alta prevalencia de sobrepeso $u$ obesidad. La encuesta ACTION-IO, realizada en personas con obesidad ( $\mathrm{PcO}$ ) $y$ profesionales de la salud (PdS), identificó las percepciones, actitudes y barreras para lograr un efectivo manejo de la obesidad. Objetivos: Informar los resultados de la encuesta en Chile. Material y Métodos: Se realizó una encuesta on-line en 11 países. En Chile, las PcO elegibles fueron adultos con un indice de masa corporal $\geq 30 \mathrm{~kg} / \mathrm{m}^{2}$ y los PdS eran médicos que realizaban atención directa de pacientes. Resultados: En Chile, la encuesta fue completada por 1000 PcO y 200 PdS. Un
${ }^{1}$ Centro Avanzado de Medicina Metabólica y Nutrición, Las Condes, Santiago, Chile. ${ }^{2}$ International Atherosclerosis Society, Viale Piave, 35, Milan, Italy.

${ }^{3}$ Departamento de Obesidad y Diabetes, Clínica Universidad de Los Andes, Las Condes, Santiago, Chile.

${ }^{4}$ Departamento de Cirugía Universidad de Chile, Independencia, Chile. ${ }^{5}$ Novo Nordisk A/S, Søborg, Denmark.

Financial support statement: Research relating to this manuscript was funded by Novo Nordisk. Three of the 17 study steering committee members were medical doctors employed by Novo Nordisk and contributed to the design of the study. One author is an employee of Novo Nordisk and participated in interpretation of the data and drafting and revision of the manuscript, and reviewed and approved the final, submitted version.

Declaration of interests A. Cuevas reports personal fees from Abbott, Novo Nordisk, Teva Pharmaceutical Strategic Centre for Obesity Professional Education (SCOPE) of the World Obesity Federation and a SCOPE International Fellow.

R. Alonso has nothing to disclose. A. Contreras reports personal fees and non-financial support from AstraZeneca, non-financial support from Sanofi Aventis, personal fees from Abbott Diabetes Care, non-financial support from Boehringer Ingelheim, non-financial support from Novo Nordisk, and nonfinancial support from Eli Lilly, outside the submitted work. D. Montt has nothing to disclose. A. Rendon is an employee of Novo Nordisk A/Industries during the conduct of the study; she is a member of the $\mathrm{S}$. 
Recibido el 2 de junio de 2020, aceptado el 6 de enero de 2021.

Correspondencia a:

Ada Cuevas

Colina del Mirador 2365, Las

Condes, Chile.

acuevas@cammyn.cl
74\% de las $\mathrm{PcO}$ y $95 \%$ de los PdS consideraron que la obesidad es una enfermedad crónica. La mayoría de las $P c O$ (79\%) asumieron su total responsabilidad en la pérdida de peso, mientras que el $47 \%$ de los PdS consideraron que la pérdida de peso era responsabilidad exclusiva de los pacientes. Un 82\% de las PcO y 97\% de los PdS estimaron que la falta de ejercicio era una importante barrera para la pérdida de peso. Además, las $\mathrm{PcO}(66 \%)$ y los PdS (58\%) refirieron que el costo de los programas, medicamentos y otros servicios constituyen barreras para el control del peso. Un $44 \%$ de las $\mathrm{PcO}$ y un $26 \%$ de los PdS consideraron que factores genéticos dificultaban la baja de peso. Solo el 19\% de los PdS pensaban que sus pacientes estaban motivados para perder peso, mientras que el $55 \%$ de las $\mathrm{PcO}$ afirmaron estar motivados. La mayoría de las $\mathrm{PcO}$ (70\%), había discutido el problema del peso con algún PdS en los últimos cinco años. De aquellas que no lo habian hecho, el 89\% deseaba entablar una conversación sobre el peso con algún PdS. Conclusiones: Los datos chilenos revelan percepciones y creencias discordantes entre PcO y PdS sobre la obesidad, destacando así la necesidad de mejorar la educación sobre su base biológica y manejo clínico.

Palabras clave: Obesidad; Percepción; Personal de Salud.

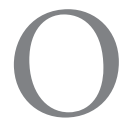
besity is a global epidemic with a high burden of disease and increasing health-related $\operatorname{costs}^{1-3}$. It is considered a complex chronic disease, and contributors to the global rise in prevalence of obesity are multifactorial including genetics, physiology, behavior, environmental, and socio-economic, among others ${ }^{4,5}$. The disease is associated with a variety of complications including type 2 diabetes, hypertension, cardiovascular events, chronic kidney disease, musculoskeletal disorders, and cancer ${ }^{6}$, and is a key risk factor for vulnerability to COVID- $19^{7}$. In Chile, the latest national health survey reported that $74 \%$ of the population has overweight or obesity, which is the highest among Organisation for Economic Co-operation and Development (OECD) countries ${ }^{3}$.

Lifestyle interventions and behavioral therapy are recommended as first lines of treatment for people with obesity $(\mathrm{PwO})^{8-10}$; however, treatment strategies based on promoting healthy eating habits and exercise often result in modest weight loss $^{11,12}$, and long-term weight regain is frequent due to the metabolic adaptation to weight loss ${ }^{4,66}$. Furthermore, in routine practice, $\mathrm{PwO}$ often receive suboptimal care due to the challenges with managing obesity including less time available to provide counselling ${ }^{13}$. This is demonstrated by low rates of obesity diagnosis, discussions, and management ${ }^{13-17}$.

Public health interventions implemented to decrease obesity in Chile include food labelling (foods high in calories, saturated fat, sodium, or sugar have precautionary labels ${ }^{18}$, school-based health programs ${ }^{3}$, and programs that advocate a holistic approach to a healthy lifestyle ${ }^{18}$. Despite the availability of evidence-based guidelines, and public health interventions, the prevalence of obesity continues to rise in both adults and children $^{19}$. To improve obesity care and treatment, a better understanding of the perceptions, beliefs, and behaviors of both healthcare professionals (HCPs) and PwO and identification of the local barriers are required.

The objective of the ACTION IO study was to identify the perceptions, attitudes, behaviors, and barriers to effective obesity care across $\mathrm{PwO}$ and HCPs. The primary results from the global ACTION-IO dataset have been reported previously ${ }^{20}$. Here we report the results from the ACTION-IO survey of PwO and HCPs in Chile.

\section{Patients and Method}

Methodology for the ACTION-IO survey has been previously reported ${ }^{20}$. Briefly, it was a cross-sectional, non-interventional descriptive study that collected data via an online survey among PwO and HCPs conducted in 11 countries. Participants in Chile completed the survey between June 4, 2018 and July 25, 2018. In Chile, 
ethical approval was determined to be non-essential for a study of this nature based on regulatory standards and precedent. The study was sponsored by Novo Nordisk, conducted in accordance with the Guidelines for Good Pharmacoepidemiology ${ }^{21}$ and Declaration of Helsinki, and is registered with ClinicalTrials.gov (NCT03584191). All respondents provided electronic informed consent prior to initiation of the screening questions and survey. Additional details regarding study methodology in Chile can be found in the supplementary appendix.

Eligible $\mathrm{PwO}$ were $\geq 18$ years old with a current body mass index (BMI) (based on self-reported height and weight) of $\geq 30 \mathrm{~kg} / \mathrm{m}^{2}$. Eligible HCPs had $\geq 2$ years in direct patient practice, and had seen $\geq 10 \mathrm{PwO}$ in the past month ${ }^{2}$. The final $\mathrm{PwO}$ sample was subsequently weighted to represent demographic targets. HCP data were monitored for specialist types but were not weighted.

\section{Results}

\section{Baseline characteristics and demographics}

In Chile, the ACTION-IO survey was completed by 1,000 PwO and 200 HCPs (Table 1). The mean age of $\mathrm{PwO}$ was 38 years, $62 \%$ were female, and the majority had Class I obesity (body mass index [BMI] $30.0-34.9 \mathrm{~kg} / \mathrm{m}^{2}$ ).

\section{$\mathrm{PwO}$ and HCP perceptions of obesity}

Overall, $74 \%$ of $\mathrm{PwO}$ and $95 \%$ of HCPs considered obesity to be a chronic disease. A majority of $\mathrm{PwO}(87 \%)$ and HCPs $(86 \%)$ believed that obesity would have a substantial impact on overall health, and most $\mathrm{PwO}(85 \%)$ were concerned their current weight would have an effect on their health in the future. PwO (78-92\%) and HCPs (82-99\%) stated that the following conditions would have a large impact on overall health: diabetes, stroke, cancer, or chronic obstructive pulmonary disease (Figure 1).

\section{Attitudes and barriers to weight loss}

Most PwO assumed complete responsibility for their weight loss (79\%) and considered lifestyle a key factor in their struggle with obesity $(70 \%$; Figure 2). Almost half of HCPs (47\%) placed the responsibility for weight loss solely on $\mathrm{PwO}$, and $80 \%$ agreed that their patients would need to alter their lifestyles to lose weight. Few HCPs (19\%) thought that their patients were motivated to lose weight, whereas $55 \%$ of $\mathrm{PwO}$ felt that they were motivated (Figure 2). Furthermore, few PwO $(13 \%)$ responded that they had no plans for weight loss within the next 6 months.

Both $\mathrm{PwO}(82 \%)$ and HCPs (97\%) believed that lack of exercise was the principal barrier to weight loss (Figure 3). Perception of other weight loss barriers differed between the subgroups. The next important barrier for $\mathrm{PwO}(71 \%)$ was cost of healthy food and for HCPs (95\%) was unhealthy eating habits. Both $\mathrm{PwO}(66 \%)$ and HCPs (58\%) felt that the cost of weight management medication, programs, and services was another barrier. More PwO (44\%) compared with HCPs (26\%) felt that genetic factors prevented weight loss.

\section{Weight loss attempts and success}

Most PwO (89\%) reported that they had made at least one serious attempt at weight loss (Figure $4 \mathrm{~A})$. In contrast, HCPs considered that only $27 \%$ (mean) of their patients with obesity had made a serious weight loss attempt (Figure 4B). Although most PwO (72\%) believed they could lose weight if they set their mind to it (Figure 2), they also reported struggling to lose weight and maintain long-term weight loss. Weight loss of $\geq 5 \%$ body mass over the past 3 years was reported by only $36 \%$ of $\mathrm{PwO}$; of those, only $24 \%$ were able to maintain the weight loss for $\geq 1$ year ( $9 \%$ of all $\mathrm{PwO}$ ). Weight loss of $\geq 10 \%$ body mass over the past 3 years was reported by $18 \%$ of $\mathrm{PwO}$.

\section{Time to acknowledging obesity and obesity-rela- ted conversations with $\mathrm{HCPs}$}

The mean age that $\mathrm{PwO}$ began to struggle with their weight was 28 years. The mean time-interval between when PwO said they first started struggling with excess weight and when they first discussed weight with an HCP was 4 years (Figure 5A). The majority of $\mathrm{PwO}$ (89\%) would like their HCP to initiate a discussion about weight with them. Many $\mathrm{PwO}$ (70\%) reported discussing their weight with their HCP in the past 5 years (Figure $5 \mathrm{~B})$. Furthermore, $42 \%$ of $\mathrm{PwO}$ who had a weight conversation with an HCP reported initiating the conversation themselves. HCPs reported discussing weight with $76 \%$ of their patients with obesity and that $28 \%$ of the time a patient initiated the conversation. A patient having obesity-related 
Table 1. Sample demographics and characteristics

\begin{tabular}{|c|c|c|}
\hline & Pwo & HCPs \\
\hline Survey invitations sent, $\mathrm{n}$ & 57,511 & 1,376 \\
\hline Survey response rate, n (\%) & $11,518(20 \%)$ & $393(29 \%)$ \\
\hline Eligibility rate, n (\%) & $1,652(15 \%)$ & $252(79 \%)$ \\
\hline Completion rate, n (\%) & $1,000(83 \%)$ & $200(98 \%)$ \\
\hline \multirow[t]{2}{*}{ Mean completion time, minutes } & 36 & 50 \\
\hline & $\begin{array}{c}\text { Pwo } \\
(n=1,000)\end{array}$ & $\begin{array}{c}\text { HCPs } \\
(n=200)\end{array}$ \\
\hline Mean age, years (range) & $38(18-75)$ & $39(27-73)$ \\
\hline \multicolumn{3}{|l|}{ Gender, n (\%) } \\
\hline Male & $382(38)$ & $108(54)$ \\
\hline Female & $615(62)$ & $92(46)$ \\
\hline Other & $3(<1)$ & - \\
\hline \multicolumn{3}{|l|}{ BMI classification, n (\%) } \\
\hline Respondents & $1,000(100)$ & $180(90)$ \\
\hline Underweight or healthy range $\left(<25 \mathrm{~kg} / \mathrm{m}^{2}\right)$ & - & $111(62)$ \\
\hline Overweight $\left(25-29.9 \mathrm{~kg} / \mathrm{m}^{2}\right)$ & - & $59(33)$ \\
\hline Obesity Class I (30-34.9 kg/m²) & $681(66)$ & $9(5)$ \\
\hline Obesity Class II (35-39.9 kg/m²) & $201(22)$ & - \\
\hline Obesity Class III ( $\geq 40$ kg/m²) & $118(12)$ & $1(1)$ \\
\hline \multicolumn{3}{|l|}{ Number of comorbidities among PwO, n (\%) } \\
\hline 0 & $183(18)$ & \\
\hline 1 & $202(20)$ & \\
\hline 2 & $223(22)$ & \\
\hline 3 & $150(15)$ & \\
\hline$\geq 4$ & $242(24)$ & \\
\hline \multicolumn{3}{|l|}{ HCP category, n (\%) } \\
\hline PCP (General practitioner) & & $100(50)$ \\
\hline Specialist & & $100(50)$ \\
\hline Diabetologist/endocrinologist & & $22(22)$ \\
\hline Obstetrician/gynecologist & & $25(25)$ \\
\hline Nutritionist & & $3(3)$ \\
\hline \multicolumn{3}{|l|}{ HCP obesity expertise, $n(\%)$} \\
\hline Sees $50 \%$ or more of patients for obesity management & & $101(51)$ \\
\hline Received advanced formal training in treatment of obesity & & $63(32)$ \\
\hline $\begin{array}{l}\text { Considers self to be an expert in obesity/weight loss management or works in } \\
\text { obesity service clinic }\end{array}$ & & $42(21)$ \\
\hline Fulfills all above criteria & & $22(11)$ \\
\hline
\end{tabular}

All N sizes for PwO are from unweighted data. Demographic percentages (age, gender, education) also are from unweighted data. All non-demographic percentage results are for PwO weighted data. HCP data were not weighted, therefore N sizes and percentages are all unweighted data for HCPs. Comorbidities that Chilean PwO were diagnosed with by an HCP were: depression/anxiety (39\%); high cholesterol (34\%); hypertension (31\%); pre-diabetes (23\%); stomach or intestinal problems (18\%); osteoarthritis (14\%); type 2 diabetes (12\%); polycystic ovary syndrome (10\%); obstructive sleep apnea (9\%); liver disease (8\%); eating disorder (5\%); cardiovascular diseases (5\%); metabolic syndrome (4\%); Cancer (4\%); infertility (2\%); other (11\%); none of these (18\%). BMI Body mass index; HCP Healthcare professional; PCP Primary care physician; PwO People with obesity. 


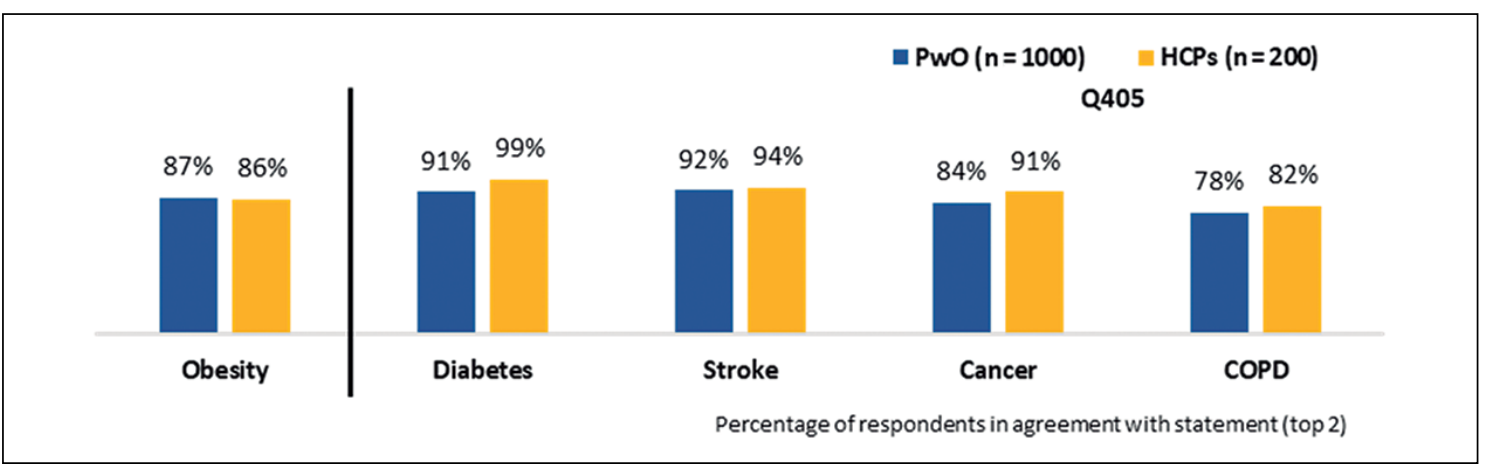

Figure 1. Impact of health conditions on overall health. Agreement was rated on a Likert scale of 1-5, with responses of 4 and 5 coded and reported as agree. Abbreviations: COPD, chronic obstructive pulmonary disease; $\mathrm{HCP}$, healthcare professional; PwO, person with obesity; Q, question.

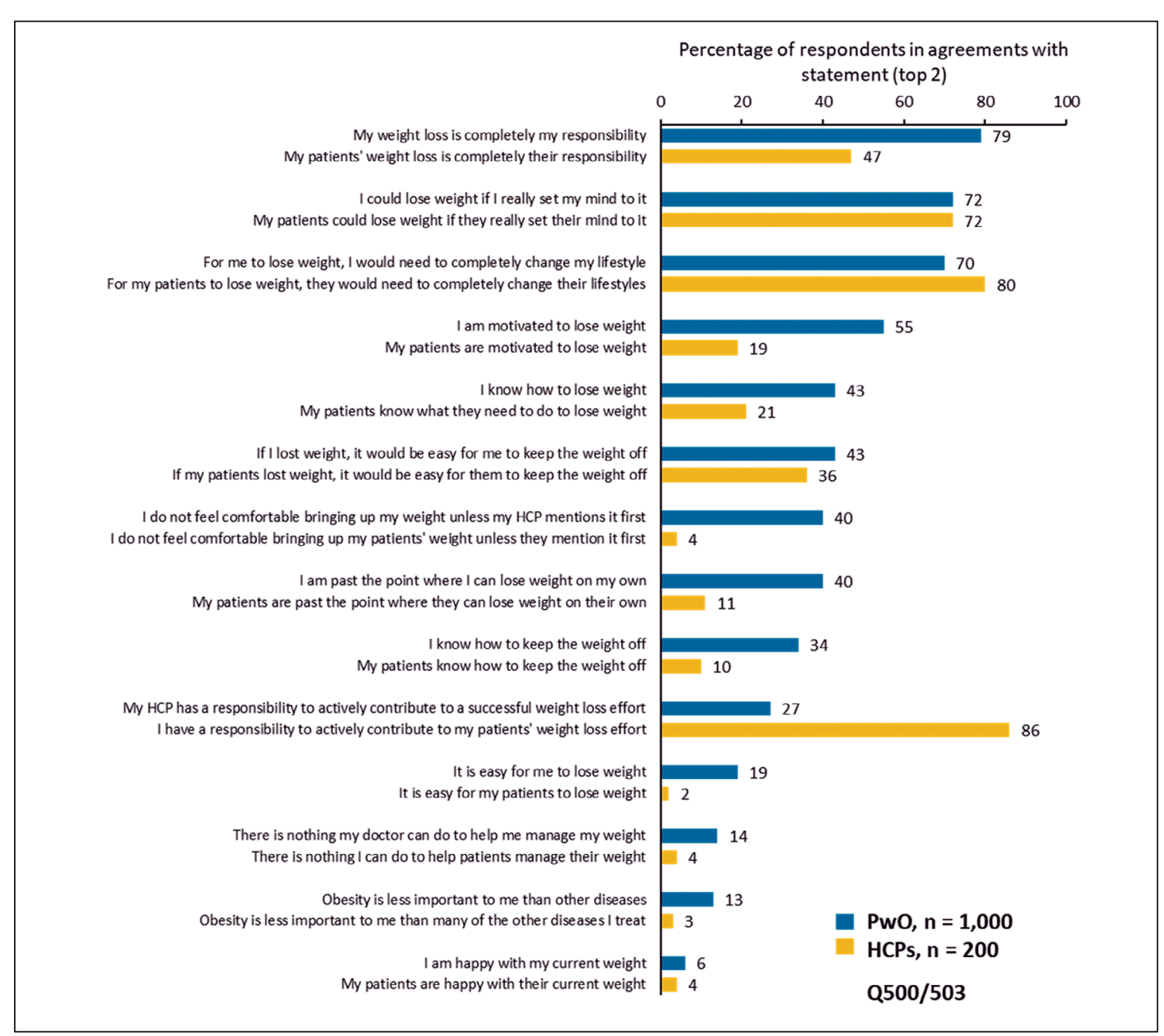

Figure 2. Attitudes towards obesity. PwO and HCP agreement with statements concerning attitudes towards obesity in Chile. Agreement was rated on a Likert scale of $1-5$, with responses of 4 and 5 coded and reported as agree. HCPs = yellow; PwO = blue. HCP Healthcare professional; PwO People with obesity; Q, question. 


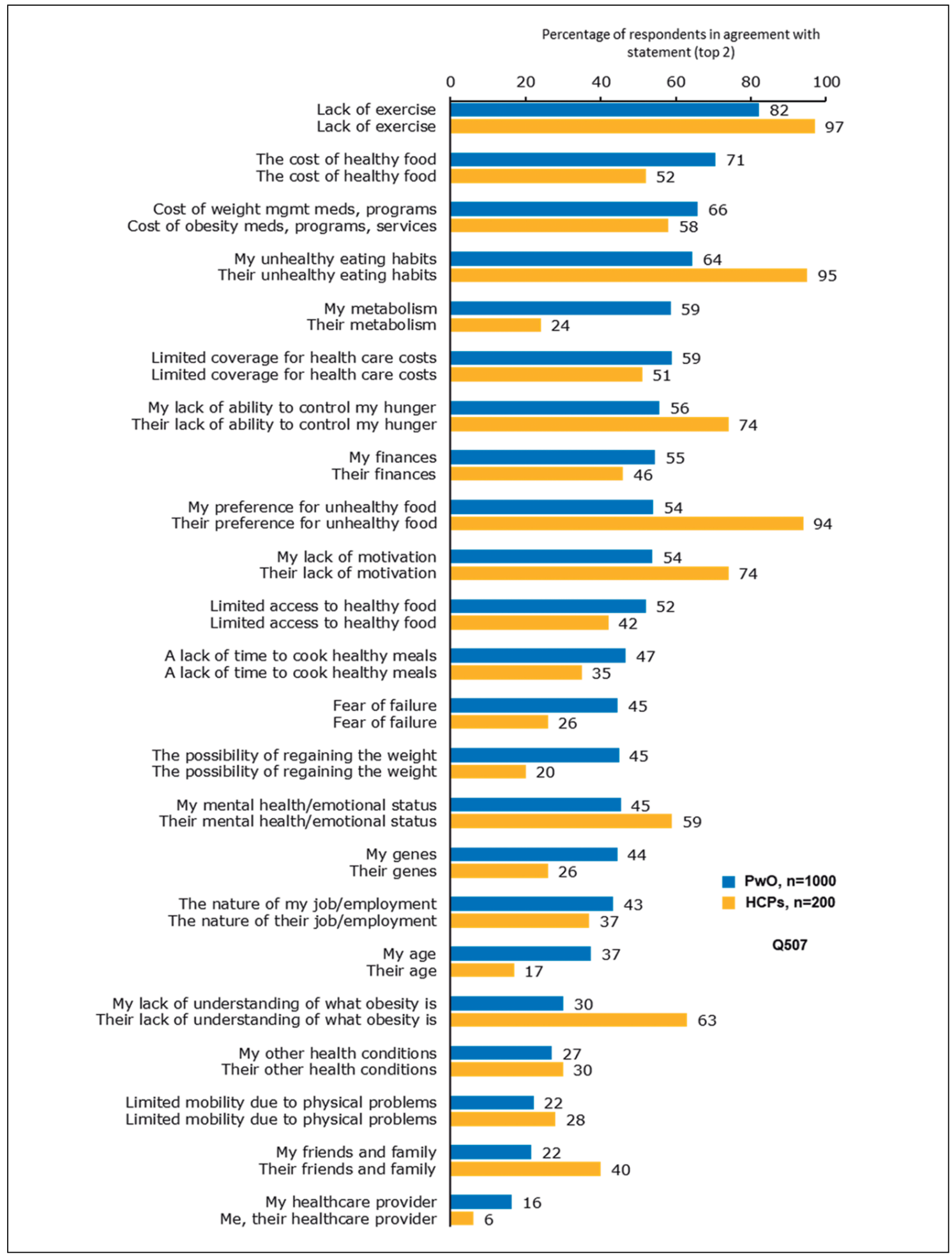

Figure 3. Weight loss barriers. Agreement was rated on a Likert scale of 1-5, with responses of 4 and 5 coded and reported as agree. Abbreviations: HCP, healthcare professional; PwO, person with obesity; Q, question. 
A

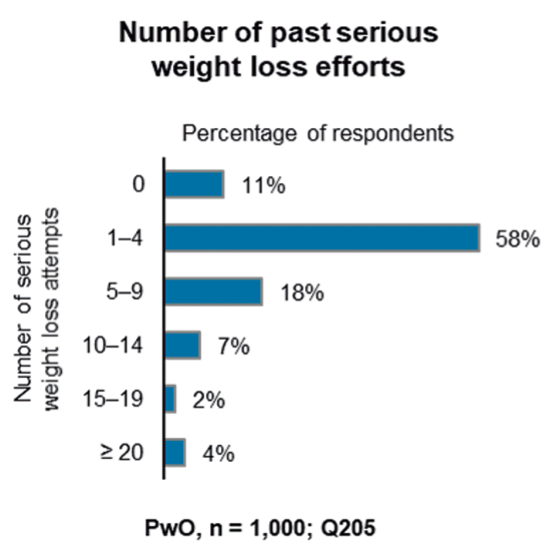

B

\section{Proportion of patients who made a serious effort to lose weight}

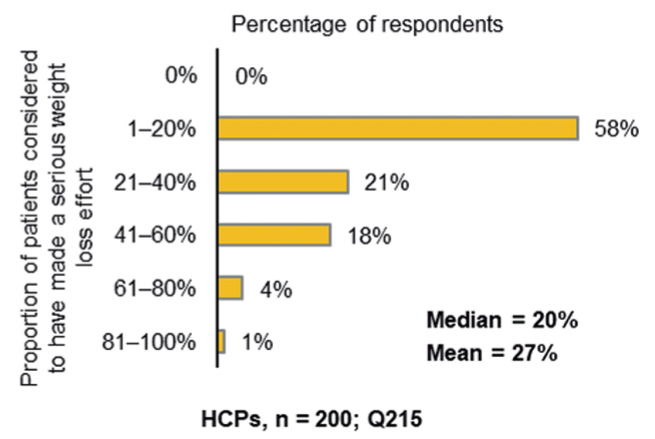

Figure 4. Weight loss attempts and results of intervention in Chile. (A) Number of past serious weight loss efforts reported by PwO. (B) Proportion of patients who HCPs considered to have made a serious effort to lose weight. HCPs = yellow; PwO = blue. HCP Healthcare professional; PwO People with obesity; Q, question.

comorbidities was the main reason HCPs cited for initiating a weight management conversation (80\%).

HCPs informed $89 \%$ of their patients that they had a diagnosis of obesity. Fewer than half of PwO (41\%) who had discussed their weight with an HCP had a follow-up appointment/call scheduled (29\% of all $\mathrm{PwO}$; Figure 5B). However, nearly all of $\mathrm{PwO}$ with a scheduled follow-up appointment/ call reported attending or planning to attend the appointment (96\%). HCPs reported scheduling follow-up appointments with $35 \%$ of their patients with obesity to discuss weight and said that $48 \%$ of their patients kept these follow-up appointments either always or most of the time.

\section{PwO attitudes towards obesity-related conversa- tions with HCPs}

At least $80 \%$ of PwO liked or would like their HCP to bring up weight during their appointments, and $46 \%$ of PwO said conversations with their HCP about weight management were either very or extremely helpful. A similar proportion of $\mathrm{PwO}(53 \%)$ reported positive types of feelings after discussing their weight with their $\mathrm{HCP}$, with $27 \%$ feeling motivated afterwards (Figure 5C). However, $51 \%$ of $\mathrm{PwO}$ reported negative types of feelings after a weight discussion, although only $3 \%$ reported feeling offended (Figure $5 \mathrm{C}$ ).
For $\mathrm{PwO}$, the top reason for not discussing weight management with their HCP was a lack of financial means to support a weight loss effort (51\%; Figure 6). In contrast, the top reason HCPs cited for not discussing obesity with a patient was the perception that the patient was not interested in losing weight (84\% HCPs vs 3\% PwO; Figure 6). Additionally, $67 \%$ of HCPs responded that limited appointment time or feeling rushed was a factor in not having a weight loss conversation (Figure 6).

\section{Weight loss goals}

When asked to set a target weight as an outcome of a weight loss effort, $49 \%$ of $\mathrm{PwO}$ would choose an ambitious target of 11-20\% body weight loss (overall mean 20\%). Similarly, $\mathrm{PwO}$ reported a mean target of $19 \%$ body weight loss from HCPs. The most frequent methods for managing weight recommended by HCPs and as recalled by $\mathrm{PwO}$ who discussed weight with HCPs were general improvements in eating habits $(63 \%$ HCPs vs $52 \% \mathrm{PwO})$ and general increases in physical activity level (67\% HCPs vs $35 \% \mathrm{PwO})$. The most effective methods of weight management found by both HCPs and $\mathrm{PwO}$ who made weight loss efforts were general increases in physical activity $(87 \%$ HCPs vs $59 \% \mathrm{PwO}$ ) and improvements in eating habits ( $82 \% \mathrm{HCPs}$ vs $58 \% \mathrm{PwO})$. More HCPs felt that visiting a dietitian was effective when 
A Time between started struggling with weight and had a weight management conversation

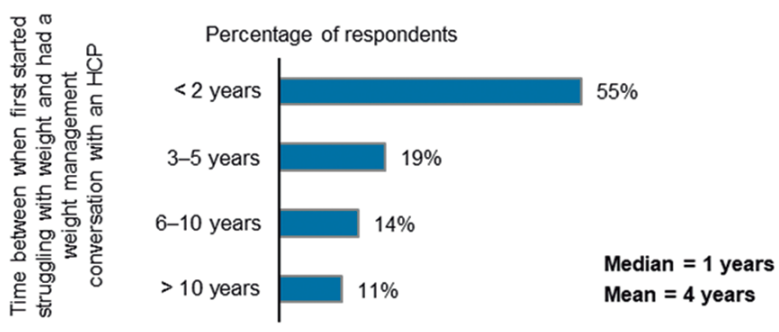

PwO who discussed weight with HCP in the past 5 years; data calculated at respondent level from questions Q122 and Q122A $(n=711)$

B Proportion of PwO having conversations about their weight, obesity diagnoses, and follow-up appointments/calls

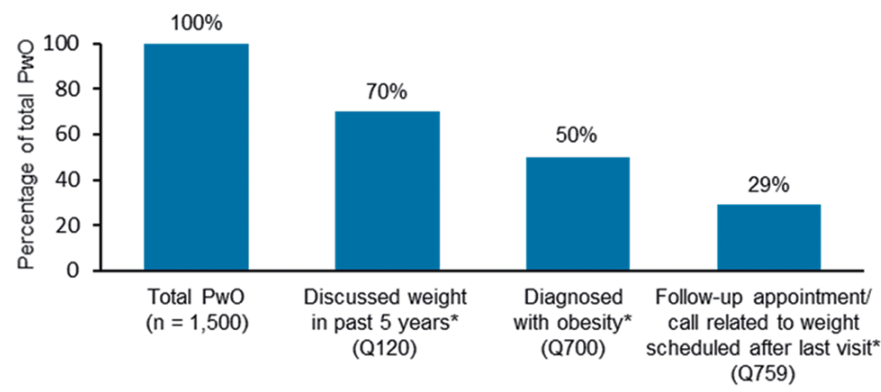

C Pwo feelings after weight management discussion

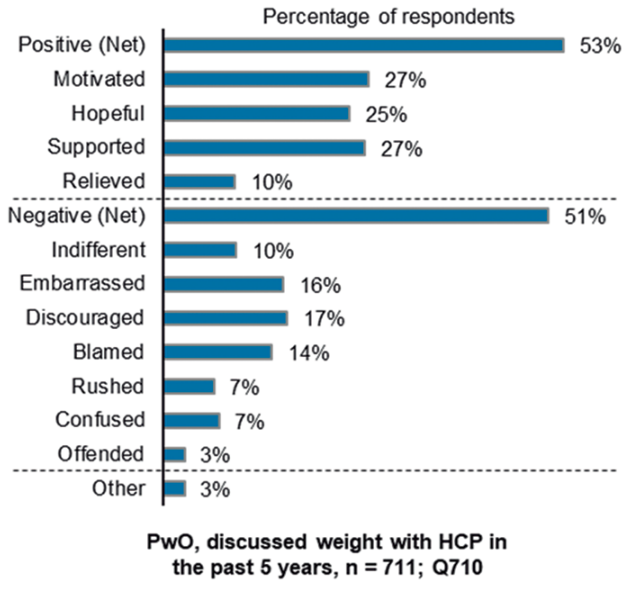

Figure 5. Discussions of weight management and outcomes in Chile. (A) Proportion of PwO who after struggling with their weight then discussed their weight with an HCP in the past 5 years. (B) Proportion of PwO having conversations about their weight with an HCP in the past 5 years, obesity diagnoses, and follow-up appointments/calls. (C) Feelings PwO reported having after discussing their weight with an HCP. HCP Healthcare professional; PwO People with obesity; Q, question. 


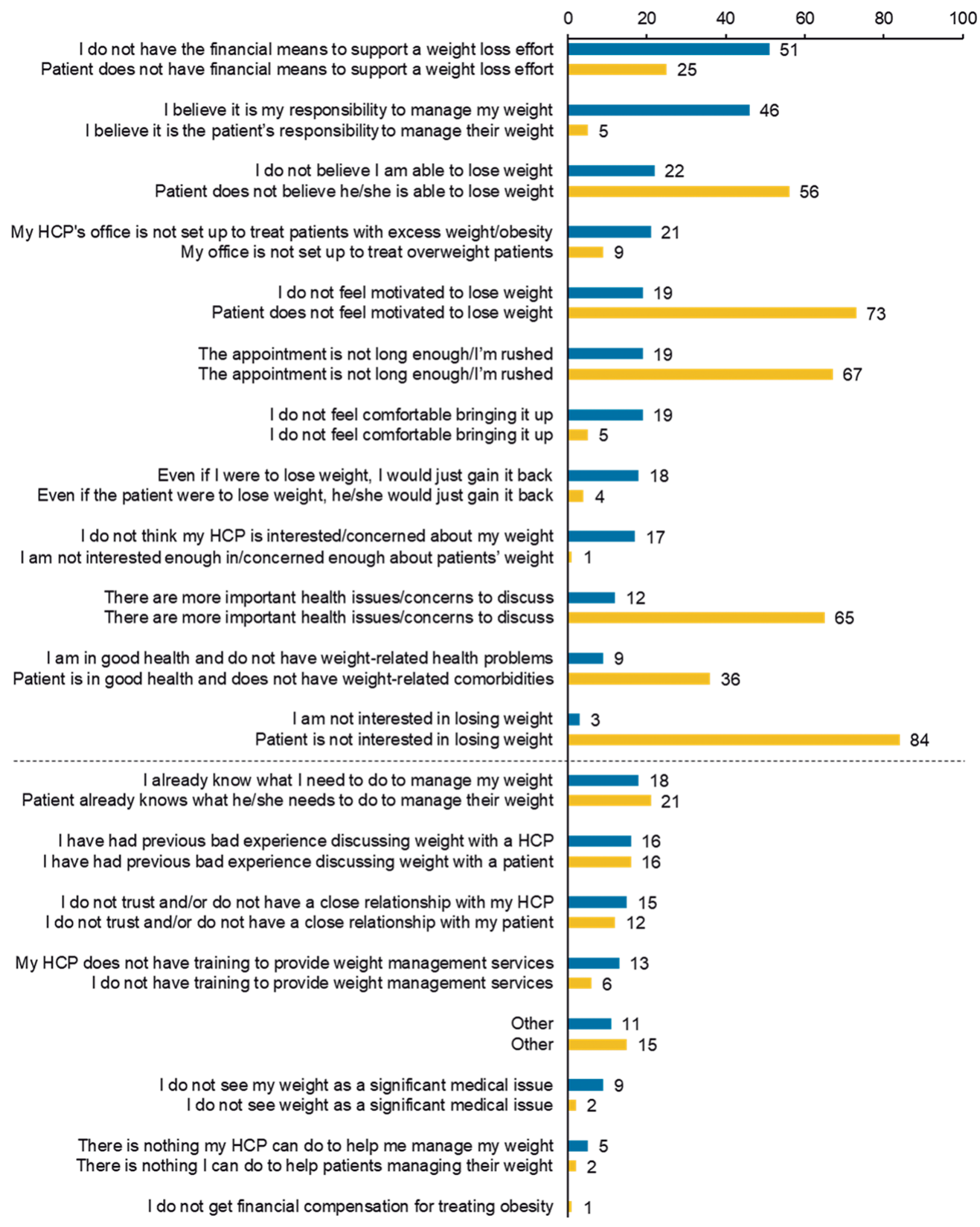

— PwO, $\mathrm{n}=1,000 ;=\mathrm{HCPs}, \mathrm{n}=200 ; \mathrm{Q770/708}$

Figure 6. Reasons PwO gave for not discussing weight with an HCP (blue) and reasons HCPs gave for not discussing weight with patients (yellow) in Chile; reasons with at least 10\% difference in response between PwO and HCPs are above the dotted line; all others are below the dotted line. Respondents selected their top 5 reasons from the list of options. HCP Healthcare professional; PwO People with obesity; Q, question. 
compared with $\mathrm{PwO}$ who had tried this method of weight loss (65\% HCPs vs $27 \% \mathrm{PwO}$ ). However, many $\mathrm{PwO}(60 \%)$ found prescription weight loss medication to be effective, in contrast to the few HCPs $(25 \%)$ who believed in the efficacy of this method for long-term weight loss, which may stem from concerns on long-term safety $(84 \%)$ and side effects associated (83\%) with prescription weight loss medications. While behavior therapy or psychotherapy as methods to manage weight were discussed infrequently by $\mathrm{HCPs}$ and $\mathrm{PwO}$ who had weight-related conversations with their provider (4\% HCPs vs $22 \% \mathrm{PwO}$ ), $32 \%$ of $\mathrm{PwO}$ who tried these methods found them effective and $42 \%$ of HCPs felt that they were effective methods for long-term weight management. Most HCPs $(\geq 80 \%)$ felt that physicians who specialize in obesity or nutrition, or a non-physician dietitian, either were or would be the most effective in helping $\mathrm{PwO}$ achieve their weight loss goals. Many $\mathrm{PwO}(65 \%)$ considered increasing the number of HCPs who manage obesity as a chronic disease as an important factor in improving the success of weight loss efforts.

\section{Discussion}

The Chilean ACTION-IO results highlight misperceptions among $\mathrm{PwO}$ and HCPs about obesity; these constitute barriers for diagnosis and evidence-based clinical management. The negative attitudes of HCPs towards $\mathrm{PwO}$ that have been reported previously in ACTION US ${ }^{17}$, ACTION Canada ${ }^{22}$, the ACTION-IO global cohort ${ }^{20}$, and other studies ${ }^{23,24}$ were also found in this study, demonstrating the importance of eradicating the misperception that $\mathrm{PwO}$ are neither interested nor motivated in losing weight. Both $\mathrm{PwO}$ and HCPs emphasized lifestyle factors were significant barriers to weight loss, potentially contributing to PwO's assumption of full responsibility for weight loss. That most $\mathrm{PwO}$ assume complete responsibility for their weight loss was a common result found in this and other ACTION-IO country cohorts $\left(\right.$ Spain $^{25}$, Italy ${ }^{26}$, South Korea ${ }^{27}, \operatorname{Japan}^{28}$ ), and in ACTION US ${ }^{17}$ and ACTION Canada ${ }^{22}$. This misperception could represent an additional barrier to effective weight management since weight stigma, including self-directed stigma whereby PwO blame themselves, has been associated with unhealthy eating, exercise avoidance, increased sedentary behavior, and poor mental health ${ }^{29}$. More PwO than HCPs regarded biological factors, including genetics, as contributors of obesity, demonstrating a need for HCP education on the multifactoral $l^{4,5}$ etiology of obesity.

Most HCPs and PwO felt that PwO could lose weight if they set their mind to it, and both $\mathrm{PwO}$ and HCPs set unrealistic weight loss goals for $\mathrm{PwO}$. Despite the majority of $\mathrm{PwO}$ having made at least one serious weight loss attempt, most $\mathrm{PwO}$ struggled to lose weight and maintain weight loss on their own as demonstrated by the low proportion of $\mathrm{PwO}$ who achieved and maintained $5 \%$ or $10 \%$ weight loss. Achieving and maintaining weight loss can be difficult in the long-term due to the metabolic adaptation to weight loss ${ }^{4,6}$. Guidelines suggest a realistic goal of 5-10\% weight loss can be expected with comprehensive multicomponent lifestyle therapy (diet, exercise, and behavior therapy $)^{9}$. In line with HCPs' perceptions of the barriers to weight loss, general improvements in diet and exercise were the most recommended and perceived efficacious methods of long-term weight loss by HCPs. While behavioral therapy and psychotherapy were addressed infrequently by HCPs when discussing methods of weight loss with their patients, almost half felt that those were effective methods for long-term weight control. Alternatively, prescription weight loss medication was the most commonly reported effective weight loss method that PwO had tried.

Since lack of weight discussions between HCPs and $\mathrm{PwO}^{16,17}$ and lack of obesity diagnosis ${ }^{14,17}$ have previously been identified as barriers to effective treatment, it was encouraging that versus other ACTION-IO cohorts, the Chilean data showed that a high proportion of $\mathrm{PwO}$ had discussed excess weight or losing weight with their HCP $(70 \%$ versus $24-67 \%)^{20,25-28}$ and Chilean HCPs reported diagnosing a higher proportion of their patients with obesity ( $89 \%$ versus $62-75 \%$, except Italy $83 \%)^{20,26-28}$. In addition, Chilean PwO reported shorter gaps between when they first began struggling with their weight and when they first had a weight management conversation with their HCP (mean 4 years versus mean 6 years, except South Korea mean 1 year $)^{20,25-28}$. However, it is important for HCPs to understand that Chilean PwO reported beginning to struggle with their weight at a younger age (mean age 28 years versus 
mean age 33-39 years; ACTION-IO study steering committee, personal communication $)^{25,27}$ so early intervention is important.

In contrast to the other ACTION-IO cohorts $^{20,25-28}$, ACTION US ${ }^{17}$, and ACTION Canada ${ }^{22}$, the financial burden of weight loss and a healthy lifestyle was a considerable obstacle for PwO in Chile. The top reason for not discussing weight with an HCP in Chile was a lack of financial means, selected by more than half of $\mathrm{PwO}$; in comparison, less than a third of $\mathrm{PwO}$ in the other ACTION studies (range 21-30\%) cited this reason ${ }^{17,20,25-28}$. Cost of healthy food, weight loss medications and programs, and limited coverage of healthcare were important weight loss barriers reported by $\mathrm{PwO}$. Out-of-pocket expenditures are a known barrier to effective medical care, and Chile has one of the highest proportions for out-of-pocket healthcare expenditures in the $\mathrm{OECD}^{30}$. Additionally, 3.1\% of Chilean households experienced catastrophic healthcare expenditures in $2017^{30}$. In the future, these results should be taken into consideration when developing strategies to manage obesity in Chile, especially as it is unlikely that $\mathrm{PwO}$ will succeed in a weight loss attempt if they cannot afford to fully participate.

The limitations of this study were identical to those corresponding to the global ACTION-IO including the cross-sectional design, and the self-reported information provided by $\mathrm{PwO}$ and HCPs, which depended on accuracy of participant recall. The strengths of the study were the large number of participants, the scientific quality of the survey questions, and the screening criteria applied to participants to provide a cohort representative of the general Chilean population.

In conclusion, the Chilean ACTION-IO results suggested that most $\mathrm{PwO}$ recognized the impact of excess weight on health and despite significant financial barriers, they were making serious efforts to lose weight but had limited success alone. HCPs need to recognize that $\mathrm{PwO}$ were motivated and interested in losing weight, which should encourage them to initiate weight management discussions. Our study indicates an opportunity for improving obesity management through multiple strategies: 1) further education of both PwO and HCPs concerning realistic weight loss targets; 2) providing education on the biological basis of obesity ${ }^{5}$ and evidence-based guidelines for effective treatment including the value of a multidisciplinary approach with possible adjunctive medical and surgical treatment ${ }^{8-10}$; 3 ) challenging the misperception that obesity is easily controllable by $\mathrm{PwO}^{23,29}$; 4) increasing the number of follow-up appointments and referrals to specialists and/or evidence-based treatment programs; and 5) further education on how prescription medication therapy can assist $\mathrm{PwO}$ in their weight management.

Acknowledgments: This study was sponsored by Novo Nordisk, which also provided financial support for medical editorial assistance from Cassandra Krone, $\mathrm{PhD}$, of Articulate Science.

\section{References}

1. NCD Risk Factor Collaboration (NCD-RisC). Worldwide trends in body-mass index, underweight, overweight, and obesity from 1975 to 2016: a pooled analysis of 2416 population-based measurement studies in 128.9 million children, adolescents, and adults. Lancet (London, England) 2017; 390 (10113): 2627-42.

2. GBD 2015 Obesity Collaborators. Health Effects of Overweight and Obesity in 195 Countries over 25 Years. N Engl J Med 2017; 377 (1): 13-27.

3. OECD. The Heavy Burden of Obesity: The Economics of Prevention. Vol OECD Health Policy Studies. Paris: OECD Publishing; 2019.

4. Bray GA, Fruhbeck G, Ryan DH, Wilding JP. Management of obesity. Lancet (London, England) 2016; 387 (10031): 1947-56.

5. Ghanemi A, Yoshioka M, St-Amand J. Broken Energy Homeostasis and Obesity Pathogenesis: The Surrounding Concepts. J Clin Med 2018; 7 (11): pii: E453.

6. Bray GA, Kim KK, Wilding JPH, World Obesity Federation. Obesity: a chronic relapsing progressive disease process. A position statement of the World Obesity Federation. Obes Rev 2017; 18: 715-23.

7. Kassir R. Risk of COVID-19 for patients with obesity. Obes Rev 2020; 21 (6): e13034.

8. Garvey WT, Mechanick JI, Brett EM, Garber AJ, Hurley DL, Jastreboff AM, et al. American Association of Clinical Endocrinologists and American College of Endocrinology Comprehensive Clinical Practice Guidelines for Medical Care of Patients with Obesity. Endocr Pract 2016; 22(Suppl 3): 1-203.

9. Jensen MD, Ryan DH, Apovian CM, Ard JD, Comuzzie AG, Donato KA, et al. 2013 AHA/ACC/TOS guideline for the management of overweight and obesity in adults: 
a report of the American College of Cardiology/American Heart Association Task Force on Practice Guidelines and The Obesity Society. Circulation 2014; 129 (25 Suppl 2): S102-38.

10. Yumuk V, Tsigos C, Fried M, Schindler K, Busetto L, Micic D, et al. European Guidelines for Obesity Management in Adults. Obesity facts 2015; 8 (6): 402-24.

11. Singh N, Stewart RAH, Benatar JR. Intensity and duration of lifestyle interventions for long-term weight loss and association with mortality: a meta-analysis of randomised trials. BMJ open 2019; 9 (8): e029966.

12. Peirson L, Douketis J, Ciliska D, Fitzpatrick-Lewis D, Ali MU, Raina P. Treatment for overweight and obesity in adult populations: a systematic review and meta-analysis. CMAJ Open 2014; 2 (4): E306-17.

13. Kraschnewski JL, Sciamanna CN, Stuckey HL, Chuang $\mathrm{CH}$, Lehman EB, Hwang KO, et al. A silent response to the obesity epidemic: decline in US physician weight counseling. Medical care 2013; 51 (2): 186-92.

14. Bleich SN, Pickett-Blakely O, Cooper LA. Physician practice patterns of obesity diagnosis and weight-related counseling. Patient education and counseling 2011; 82 (1): 123-9.

15. Huang J, Yu H, Marin E, Brock S, Carden D, Davis T. Physicians' weight loss counseling in two public hospital primary care clinics. Acad Med 2004; 79 (2): 156-61.

16. Hite A, Victorson D, Elue R, Plunkett BA. An Exploration of Barriers Facing Physicians in Diagnosing and Treating Obesity. Am J Health Promot 2019; 33 (2): 217-24.

17. Kaplan LM, Golden A, Jinnett K, Kolotkin RL, Kyle TK, Look M, et al. Perceptions of barriers to effective obesity care: results from the national ACTION study. Obesity 2018; 26 (1): 61-9.

18. Rodriguez Osiac L, Cofre C, Pizarro T, Mansilla C, Herrera CA, Burrows J, et al. Using evidence-informed policies to tackle overweight and obesity in Chile. Rev Panam Salud Publica 2017; 41: e156.

19. NCD Risk Factor Collaboration (NCD-RisC) [Internet]. NCD-RisC; c2017. Country Profile: Chile; 2017 [cited 2019 Jan 29]. Available from: http://www.ncdrisc.org/ country-profile.html.
20. Caterson ID, Alfadda AA, Auerbach P, Coutinho W, Cuevas A, Dicker D, et al. Gaps to bridge: Misalignment between perception, reality and actions in obesity. Diabetes Obes Metab 2019; 21 (8): 1914-24.

21. International Society for Pharmacoepidemiology (ISPE) [Internet]. ISPE; c2020. Guidelines for Good Pharmacoepidemiology Practices (GPP); 2015 [cited 2019 January 15]. Available from: https://www.pharmacoepi. org/resources/policies/guidelines-08027/.

22. Sharma AM, Bélanger A, Carson V, Krah J, Langlois MF, Lawlor D, et al. Perceptions of barriers to effective obesity management in Canada: Results from the ACTION study. Clin Obes 2019; 9 (5): e12329.

23. Flint SW. Obesity stigma: Prevalence and impact in healthcare. Br J Obes 2015; 1: 14-8.

24. Dixon JB, Hayden MJ, O’Brien PE, Piterman L. Physician Attitudes, Beliefs and Barriers towards the Management and Treatment of Adult Obesity: A Literature Review. Aus J Prim Health 2008; 14 (3): 9-18.

25. Salvador J, Vilarrasa N, Poyato F, Rubio MÁ. Perceptions, attitudes, and barriers to obesity management in Spain: Results from the Spanish cohort of the international ACTION-IO observation study. J Clin Med 2020; 9 (9): E2834.

26. Sbraccia P, Busetto L, Santini F, Mancuso M, Nicoziani P, Nicolucci A. Misperceptions and barriers to obesity management: Italian data from the ACTION-IO study. Eat Weight Disord 2020. doi: 10.1007/s40519-02000907-6.

27. Lim S, Oh B, Lee SH, Kim YH, Ha Y, Kang JH. Perceptions, attitudes, behaviors, and barriers to effective obesity care in South Korea: Results from the ACTION-IO study. J Obes Metab Syndr 2020; 29 (2): 133-42.

28. Iwabu M, Yamauchi T, Shimomura I, Eguchi K, Ogawa Y. Perceptions, attitudes and barriers to obesity management: Japanese data from the ACTION-IO study. J Diabetes Investig 2020. doi: 10.1111/jdi.13427.

29. Rubino F, Puhl RM, Cummings DE, Eckel RH, Ryan $\mathrm{DH}$, Mechanick JI, et al. Joint international consensus statement for ending stigma of obesity. Nat Med 2020; 26 (4): 485-97.

30. OECD. Health at a Glance 2019: OECD Indicators. Paris: OECD Publishing; 2019. 